\title{
Methanol Leaf Extract of Desmodium Velutinum (Wild.) D.C. and Acarbose Exhibit Additive Pharmacological Effects in Diabetic Wistar Rats
}

\author{
Ozougwu V E $\mathbf{0}^{1}$, Akuba B $0^{1,2}$ and Idakwoji P A $A^{1,3 *}$ \\ ${ }^{1}$ Department of Biochemistry, Faculty of Biological Sciences, University of Nigeria, Nigeria \\ ${ }^{2}$ Department of Science Laboratory Technology, Faculty of Science, Kogi State Polytechnic, Nigeria \\ ${ }^{3}$ Department of Biochemistry, Faculty of Natural Sciences, Kogi State University, Nigeria
}

*Corresponding author: Idakwoji P A Department of Biochemistry, Faculty of Natural Sciences, Kogi State University, Anyigba, Nigeria.

To Cite This Article: Ozougwu VE O, Akuba B O, Idakwoji P A. Methanol Leaf Extract of Desmodium Velutinum (Wild.) D.C. and Acarbose Exhibit Additive Pharmacological Effects in Diabetic Wistar Rats. Am J Biomed Sci \& Res. 2021 - 14(1). AJBSR.MS.ID.001958. DOI: 10.34297/AJBSR.2021.14.001958.

Received: 畊 August 23, 2021; Published: 制 September 07, 2021

\begin{abstract}
This study investigated the pharmacological effects of methanol extract of Desmodium velutinum leaves (DVE) administered alone and when co-administered with Acarbose (ACA) in diabetic Wistar rats. Preliminary phytochemical analysis and acute toxicity study were carried out on DVE using standard methods. In the pharmacological study, diabetes was induced in rats by intraperitoneal administration of $150 \mathrm{mg}$ alloxan $/ \mathrm{kg}$ b.w. Seven groups ( 6 groups of diabetic rats and 1 group of normoglycemic rats) of four rats each were used for the study. Groups I and II served as normoglycemic (NDC) and diabetic controls (DC) respectively and received $1 \mathrm{ml}$ distilled water/kg b.w. Groups III and IV were administered 400 and $800 \mathrm{mg}$ DVE/kg respectively while groups V and VI were administered the same doses ( 400 and $800 \mathrm{mg} / \mathrm{kg}$ respectively) but co- administered with a fixed dose of ACA (150 mg/kg b.w.). Group VII was administered $150 \mathrm{mg} \mathrm{ACA} / \mathrm{kg}$ b.w. alone. Weekly fasting blood sugar (FBS) levels and body weight changes were estimated for 28 days. After the 28-day treatment regimen, rats were euthanized, and blood samples collected for serum biochemical analysis. Phytochemical analysis of DVE revealed the presence of alkaloids, phenols, flavonoids, tannins, steroids and terpenoids in varying proportions. Treatment with DVE alone and its co-administration with ACA significantly $(\mathrm{p}<0.05)$ reduced FBS and serum biochemicals parameters of rats compared with diabetic control. DVE alone and its co-administration with ACA also significantly $(\mathrm{p}<0.05)$ increased the serum total protein of rats compared with diabetic control. However, the pharmacological effects of DVE and ACA co-administration were significantly ( $p<$ 0.05) higher than that of DVE or ACA administered alone. It was concluded that DVE and ACA exhibited additive pharmacological effects in diabetic Wistar rats and as such could be useful in the management of diabetes.
\end{abstract}

Keywords: Acarbose; Pharmacological; Hyperglycemia; Desmodium velutinum; Wistar Rats

Abbreviations: DVE: Methanol Extract Of Desmodium Velutinum Leaves; ACA: Acarbose; DM: Diabetes Mellitus; IDF: International Diabetes Federation; FBS: Fating Blood Sugar; T1DM: Type 1 Diabetes Mellitus; T2DM: Type 2 Diabetes Mellitus; GDM: Gestational Diabetes Mellitus; AST: Aspartate Transaminase; ALT: Alanine Transaminase; ALP: Alkaline Phosphatase; TBIL: Total Bilirubin; TP: Total Protein

\section{Introduction}

Diabetes mellitus (DM) is a group of metabolic disorders characterized by a chronic hyperglycemic condition resulting from defects in insulin secretion, insulin action or both [1]. Hyperglycemia which is the hallmark of diabetes mellitus is responsible for its cardinal symptoms namely: weight loss, polyphagia, polydipsia and polyuria [2]. According to a recent statistics by International Diabetes Federation (IDF), the global prevalence of diabetes among adults is 6.4\%, reaching 425 million adults in 2017 and possibly 
629 million adults by 2045. Diabetes is a major cause of mortality and morbidity worldwide.

A number of pathogenic processes are involved in the development of diabetes. These range from autoimmune destruction of the $\beta$ cells of the pancreas, with consequent insulin deficiency, to abnormalities that result in resistance to insulin action [3]. The onset and progression of long: term complications in diabetes mellitus appear to be related to the degree of hyperglycemia and the overall metabolic control. It encompasses a wide range of conditions that affects either the functioning of the eyes, heart, nerves, liver, pancreas or kidney, and includes those that originates due to genetic abnormalities and infectious diseases. Despite the great strides made in the understanding and management of diabetes, the disease and disease related complications are increasing unabated due to multiple defects in its pathophysiology [4]. Consequently, there has been an increasing demand for the use of plant products with anti: diabetic activity.

Desmodium velutinum (Wild.) D.C. belongs to the family Fabaceae. It is a perennial, erect or semi: erect shrub, up to $3 \mathrm{~m}$ high, native to tropical Africa and subtropical Asia (China, Taiwan, India, Indonesia, Laos, Malaysia, Myanmar, Sri Lanka, Thailand and Vietnam). It is commonly found in the Savannah, along roadsides and in clearings from Senegal to Nigeria and from Cameroun to Angola and also in Sudan [5]. The velutinous (velvety) surface of its 1:foliloate leaf is a characteristic feature [6] . Desmodium has been used in traditional medicinal in a broad range for the treatment of headache, toothache, fever, rheumatism, jaundice, diabetes and gonorrhea [7]. To the best of our knowledge, there is little or no scientific information backing its use in the management of diabetes. Hence, this study was aimed at investigating the pharmacological effects of Desmodium velutinum and its co: administration with acarbose in diabetic Wistar rats.

\section{Materials and Methods}

\section{Collection and Identification of Plant Material}

The leaves of Desmodium velutinum were collected fresh from Oba: Nsukka, Enugu State and identified by Mr. Alfred Ozioko of Bioresources Development and Conservation Programme, Nsukka, Enugu State.

\section{Chemicals and Drugs}

Acarbose (Glucobay ${ }^{\circledR}$ Bayer), Methanol (BDH, England), Alloxan monohydrate (Sigma: Aldrich, UK), were purchased from the country representative of Sigma Chemical, St. Louis USA. A digital glucometer and corresponding test strips (Fine Test ${ }^{\circledR}$, Infopia Co., Ltd. USA) was purchased from a pharmacy store in Nsukka Local Government Area, Enugu State. All other chemicals used were of analytical grade and obtained commercially.

\section{Preparation of Methanol Leaves Extract of Desmodium velutinum}

The leaves of the plant were pulverized to coarse powder in an electric hammer mill. The plant powdered material was extracted with methanol by cold maceration with occasional shaking for 72 h. The mixture was filtered using Whatman filter paper (No 1) to obtain the filtrate. The filtrates were concentrated and evaporated to dryness on a hot water bath at $45^{\circ} \mathrm{C}$ to obtain the methanol extract. The percentage yield of the extract is $9.82 \%$ and the extract will henceforth be referred to as DVE.

\section{Phytochemical Screening}

The phytochemical composition of the extract was determined using the methods of Sofowara [8].

\section{Acute Toxicity Study}

The oral median lethal dose (LD50) of the extract was determined in rats according to the method described by Lorke [9]. The study was carried out in two phases. In the first phase, nine rats were randomized into three groups of three rats which were given DVE at doses of 10,100 , and $1000 \mathrm{mg} / \mathrm{kg}$ body weight. The rats were kept under the same conditions and observed for signs of toxicity which included but were not limited to paw: licking, stretching, respiratory distress and mortality for $24 \mathrm{~h}$. Based on the results of the initial phase, the following DVE doses: 1600, 2900 and $5000 \mathrm{mg} / \mathrm{kg}$ body weight were administered to another set of three groups of three rats in the second phase. These rats were also monitored closely for $24 \mathrm{~h}$ after treatment for signs of toxicity and/or mortality. The results obtained in the second phase were used to calculate the $\mathrm{LD}_{50}$. The $\mathrm{LD}_{50}$ was calculated as the geometric means of the maximum dose producing $0 \%$ mortality $\left(D_{0}\right)$ and the minimum dose that produced $100 \%$ mortality $\left(D_{100}\right)$ and mathematically expressed as: $\mathrm{LD}_{50}=\sqrt{ }\left(\mathrm{D}_{0} \times \mathrm{D}_{100}\right)$

\section{Induction of Hyperglycemia}

The method described by Dunn and Mc Letchie [10] was adopted for the studies. Experimental rats were fasted overnight; freshly prepared alloxan $(150 \mathrm{mg} / \mathrm{kg}$ body weight) was administered intraperitoneally. The animals were thereafter allowed food and water ad libitum. The day which alloxan was administered was considered as day 1 . After 4 days (day 5), the blood glucose levels in the rats were determined following an overnight fast, using a Fine Test $^{\circledR}$ digital glucometer and the corresponding test strip. Rats having fasting blood glucose (FBS) level $\geq 200 \mathrm{mg} / \mathrm{dl}$ were considered hyperglycemic.

\section{Experimental Protocol}

Seven (7) groups (6 groups of hyperglycemic rats and 1 group of normoglycemic rats) of four (4) animals each were used for 
the study. Group I and II will serve as the normoglycemic (NDC) and diabetic controls (DC) respectively and received $1 \mathrm{ml}$ distilled water/kg body weight. Groups III and IV rats received 400 and $800 \mathrm{mg}$ DVE/kg respectively. Groups V and VI rats were treated with these same doses (400 and $800 \mathrm{mg} / \mathrm{kg}$ respectively) but co: administered with a fixed dose of acarbose $(150 \mathrm{mg} / \mathrm{kg}$ body weight). Rats in group VII were treated with $150 \mathrm{mg}$ acarbose/ kg body weight only.

Acarbose solution was usually prepared fresh for each day's experiment to ensure stability. Treatment was carried out daily for 28 days and both the extract and acarbose solutions were freshly prepared on each day of the experiment to ensure stability.

\section{Route of Administration}

The extract of Desmodium velutinum leaves and acarbose were orally administered throughout the study.

\section{Weekly Fasting Blood Sugar (FBS) Estimation}

FBS was estimated on day 0 (i.e. day 4 post induction for the hyperglycemic sub: groups) and subsequently on days 7, 14, 21 and 28. Blood samples were collected from the tail vein with a sterile scissors and tested using the digital glucometer and its test strip

Weekly Body Weight Changes: Rats in all groups were weighed weekly during the period of treatment and on the day before diabetic induction for changes in body weight.

Serum Biochemistry: On the 28th day of the experiment, all the rats were euthanized by chloroform inhalation and blood samples were collected by cardiac puncture. The blood was collected into plain serum tubes, allowed to clot and centrifuged for 10 minutes at $3500 \mathrm{rpm}$. The homogenates were separated, stored in the refrigerator and used for evaluation of biochemical parameters, (aspartate transaminase (AST), alanine transaminase (ALT) levels, alkaline phosphatase (ALP) levels, total protein, albumin, total bilirubin (TBIL) were determined using Randox diagnostic kits. Method described by Reitman and Frankel [11] was adopted.

Statistical Analysis: All data were expressed as Mean \pm SD and statistical differences between means were determined by one: way ANOVA followed by Duncan post -hoc test for multiple comparison tests using SPSS. Values were considered significant at $\mathrm{p} \leq 0.05$.

\section{Results}

\section{Phytochemical Screening}

The Preliminary phytochemical analysis of the extract revealed the presence of tannins, alkaloid, saponins, steroid, flavonoids and terpenoids except reducing sugar and Anthraquinones.
Table 1: Preliminary phytochemical analysis of the methanol leaves extract of Desmodium velutinum.

\begin{tabular}{|c|c|}
\hline Phytochemicals & $\begin{array}{c}\text { Methanol extract of Desmodium } \\
\text { velutinum Leaves }\end{array}$ \\
\hline Tannins & +++ \\
\hline Alkaloids & +++ \\
\hline Terpenoids & ++ \\
\hline Flavonoids & ++ \\
\hline Saponins & ++ \\
\hline Steroids & ++ \\
\hline Reducing sugars & ND \\
\hline Anthraquinones & ND \\
\hline
\end{tabular}

Key: + slightly detected, ++ moderately detected, +++ highly detected, ND: Not detected

\section{Acute Toxicity Study}

In the first phase of the experiment, the methanol extract of Desmodium velutinum leaves did not show any sign of toxicity or mortality during the monitoring period at the doses administered orally. The second phase of the experiment at the dose of $5000 \mathrm{mg} /$ $\mathrm{kg}$ body weight, one sign of toxicity and mortality was recorded at the dose administered orally (Table 2). Hence the oral median lethal dose $\left(\mathrm{LD}_{50}\right)$ of the extract was therefore estimated to be $3807.8 \mathrm{mg} /$ $\mathrm{kg}$.

Table 2: Acute Toxicity Study of the Methanol Extract of Desmodium velutinum Leaves (DVE).

\begin{tabular}{|c|c|c|}
\hline Group & Treatment (mg/kg & D/T \\
\hline \multicolumn{3}{|c|}{ PHASE I } \\
\hline 1 & 10 & $0 / 3$ \\
\hline 2 & 100 & $0 / 3$ \\
\hline 3 & 1000 & $0 / 3$ \\
\hline \multicolumn{3}{|c|}{ Phase II } \\
\hline 1 & 1600 & $0 / 3$ \\
\hline 2 & 2900 & $0 / 3$ \\
\hline 3 & 5000 & $1 / 3$ \\
\hline \multicolumn{2}{|c|}{} \\
\hline D/T: Number of deaths/ number of rats treated
\end{tabular}

Effect of Methanol Extract of Desmodium velutinum Leaves (DVE), Acarbose (AC) and DVE/Acarbose co:administration on FBS of Wistar Rats

The FBS of the various diabetic groups are presented in Table 3. The mean FBS of $400 \mathrm{mg} / \mathrm{kg}$ DVE and $800 \mathrm{mg} / \mathrm{kg}$ DVE treatments showed statistically significant $(\mathrm{p}<0.05)$ decrease in FBS on day 7, 14, 21 and 28 respectively compared to diabetic control. The 
DVE/ACA: treated groups (400mg/kg DVE/ 150mg/kg ACA) and (800mg/kg DVE/ $150 \mathrm{mg} / \mathrm{kg} \mathrm{AC}$ ) equally showed statistically significant $(\mathrm{p}<0.05)$ decrease in FBS on days 7, 14, 21 and 28 respectively when compared to diabetic control. However, this was significantly $(\mathrm{p}<0.05)$ higher than the reductions produced by DVE at the two doses administered alone.

\begin{tabular}{|c|c|c|c|c|c|}
\hline \multicolumn{6}{|c|}{ Post Treatment Time (Day) } \\
\hline Treatment & 0 & 7 & 14 & 21 & 28 \\
\hline NDC & $79.8 \pm 3.77^{\mathrm{aAB}}$ & $81.7 \pm 4.27^{\mathrm{aAB}}$ & $85.3 \pm 2.99^{\mathrm{aB}}$ & $79.0 \pm 2.16^{\mathrm{aA}}$ & $82.2 \pm 3.86^{\mathrm{aAB}}$ \\
\hline DC & $486.7 \pm 25.17^{\mathrm{dA}}$ & $492.3 \pm 20.95^{\mathrm{eA}}(\mathrm{NR})$ & $491.3 \pm 16.31^{\mathrm{eA}}(\mathrm{NR})$ & $498.5 \pm 11.90^{\mathrm{fA}}(\mathrm{NR})$ & $497.7 \pm 12.68^{\mathrm{fA}}(\mathrm{NR})$ \\
\hline DVE (400mg/kg) & $448.5 \pm 25.6^{8 \mathrm{bA}}$ & $453.5 \pm 21.74^{\mathrm{dA}}(\mathrm{NR})$ & $450.5 \pm 21.55^{\mathrm{dA}}(\mathrm{NR})$ & $448.4 \pm 20.24^{\mathrm{eA}}(\mathrm{NR})$ & $441.5 \pm 15.21^{\mathrm{eA}}(1.56 \%)$ \\
\hline DVE (800mg/kg) & $471.5 \pm 3.11^{\mathrm{cdD}}$ & $448.3 \pm 5.67^{\mathrm{dC}}(4.92 \%)$ & $439.2 \pm 2.87^{\mathrm{dB}}(6.85 \%)$ & $438.7 \pm 2.38^{\mathrm{eB}}(6.96 \%)$ & $301.2 \pm 2.06^{\mathrm{dA}}(36.12 \%)$ \\
\hline $\begin{array}{c}\text { DVE }(400 \mathrm{mg} / \mathrm{kg})+\mathrm{ACA} \\
(150 \mathrm{mg} / \mathrm{kg})\end{array}$ & $450.3 \pm 2.63^{\mathrm{bcD}}$ & $233.0 \pm 3.16^{\mathrm{cC}}(48.26 \%)$ & $130.8 \pm 2.36^{\mathrm{bB}}(70.95 \%)$ & $127.8 \pm 1.50^{\mathrm{cB}}(71.62 \%)$ & $100.5 \pm 3.00^{\mathrm{bA}}(77.69 \%)$ \\
\hline $\begin{array}{c}\text { DVE }(800 \mathrm{mg} / \mathrm{kg})+\mathrm{ACA} \\
(150 \mathrm{mg} / \mathrm{kg})\end{array}$ & $472.3 \pm 1.71^{\mathrm{cdE}}$ & $200.5 \pm 2.38^{\mathrm{bD}}(57.55 \%)$ & $128.3 \pm 2.50^{\mathrm{bC}}(72.84 \%)$ & $110.6 \pm 0.96^{\mathrm{bB}}(76.58 \%)$ & $98.6 \pm 3.09^{\mathrm{bA}}(79.12 \%)$ \\
\hline ACA (150mg/kg) & $463.2 \pm 5.56^{\mathrm{bcD}}$ & $235.0 \pm 2.94^{\mathrm{Cc}}(49.27 \%)$ & $201.4 \pm 4.03^{\mathrm{cB}}(56.52 \%)$ & $199.3 \pm 3.86^{\mathrm{dB}}(56.97 \%)$ & $180.6 \pm 2.08^{\mathrm{cA}}(61.01 \%)$ \\
\hline
\end{tabular}

Data is represented as mean \pm S.D of FBS $(n=4)$. Mean values having different lowercase letters down the columns and uppercase letters across the row as superscripts are considered significant $(p<0.05)$. Values in parentheses represent percentage reduction in FBS

\section{Effect of Methanol Extract of Desmodium velutinum Leaves (DVE), Acarbose (AC) and DVE/ ACA Co: administration on Body Weight of Rats.}

A slightly statistically significant $(\mathrm{p}<0.05)$ difference was found in the mean body weight of rats in the treated groups compared with diabetic control (Table 4).

Table 4: Effect of Methanolic Extract of Desmodium velutinum Leaves (DVE), Acarbose (ACA) and DVE/ACA Co-administration on Average Body Weight of Hyperglycemic Rats.

\begin{tabular}{|c|c|c|c|c|c|}
\hline \multirow{2}{*}{ Treatment } & \multicolumn{5}{|c|}{ Post-treatment time (Day) } \\
\hline & $\mathbf{0}$ & 7 & 14 & 21 & 28 \\
\hline NDC & $161.4 \pm 11.23^{\mathrm{dA}}$ & $160.3 \pm 12.15^{\mathrm{dA}}$ & $163.2 \pm 09.63^{\mathrm{dA}}$ & $168.3 \pm 11.61 \mathrm{fB}$ & $173.1 \pm 21.13^{\mathrm{fC}}$ \\
\hline DC & $158.2 \pm 13.51^{\mathrm{cdC}}$ & $141.3 \pm 11.13^{\mathrm{aB}}$ & $138.8 \pm 13.68^{\mathrm{aB}}$ & $138.6 \pm 13.28 \mathrm{aB}$ & $123.3 \pm 13.60^{\mathrm{aA}}$ \\
\hline DVE (400mg/kg) & $160.3 \pm 15.37^{\mathrm{dBC}}$ & $153.7 \pm 12.13^{\mathrm{bcA}}$ & $158.1 \pm 17.26^{\mathrm{cdB}}$ & $154.3 \pm 16.33 \mathrm{bcA}$ & $161.6 \pm 14.67^{\mathrm{cdC}}$ \\
\hline DVE (800mg/kg) & $152.4 \pm 12.33^{\mathrm{abAB}}$ & $150.2 \pm 12.11^{\mathrm{bcA}}$ & $154.1 \pm 11.68^{\mathrm{cB}}$ & $157.4 \pm 13.28 \mathrm{cdC}$ & $159.1 \pm 13.67^{\mathrm{cC}}$ \\
\hline $\begin{array}{c}\text { DVE }(400 \mathrm{mg} / \mathrm{kg})+\mathrm{ACA}(150 \\
\mathrm{mg} / \mathrm{kg})\end{array}$ & $157.1 \pm 15.31^{\mathrm{cdA}}$ & $155.1 \pm 112.63^{\mathrm{cA}}$ & $158.3 \pm 13.23^{\mathrm{cdAB}}$ & $163.5 \pm 11.68^{\mathrm{eBC}}$ & $165.8 \pm 18.30^{\mathrm{dBC}}$ \\
\hline $\begin{array}{c}\text { DVE }(800 \mathrm{mg} / \mathrm{kg})+\mathrm{ACA} \\
(150 \mathrm{mg} / \mathrm{kg})\end{array}$ & $155.2 \pm 11.91^{\mathrm{bcAB}}$ & $151.3 \pm 15.68^{\mathrm{bcA}}$ & $159.4 \pm 13.45 \mathrm{dBC}$ & $161.6 \pm 16.23^{\mathrm{deC}}$ & $161.3 \pm 15.67^{\text {cdc }}$ \\
\hline ACA (150mg/kg) & $150.3 \pm 13.51^{\mathrm{aBC}}$ & $148.4 \pm 119.23^{\mathrm{bB}}$ & $143.3 \pm 16.21 b$ & $150.7 \pm 14.28^{\mathrm{bBC}}$ & $152.9 \pm 18.1^{\mathrm{Bac}}$ \\
\hline
\end{tabular}

Data is represented as mean \pm S.D of body weight $(n=4)$. Mean values having different lowercase letters down the columns and uppercase letters across the row as superscripts are considered significant $(p<0.05)$

\section{Effect of Methanol Extract of Desmodium velutinum Leaves (DVE), Acarbose (AC) and DVE/ACA Co:administration on some Serum Biochemical Parameters of Diabetic Rats}

The serum biochemical analysis revealed that $800 \mathrm{mg} / \mathrm{kg}$ DVE produced a statistical significant $(\mathrm{p}<0.05)$ reduction in the activities of AST, ALT and ALP, and elevation in the concentrations of TBIL, TP and ALB compared to Diabetic control. DVE/ ACA co: administration (DVE $400 \mathrm{mg} / \mathrm{kg} / \mathrm{ACA} 150 \mathrm{mg} / \mathrm{kg}$ ) and (DVE $800 \mathrm{mg} / \mathrm{kg} / \mathrm{ACA} 150 \mathrm{mg} / \mathrm{kg}$ ) showed statistically significant $(\mathrm{p}<0.05)$ produced a statistical significant $(\mathrm{p}<0.05)$ reduction in the activities of AST, ALT and ALP, and elevation in the concentrations of TBIL, TP and ALB compared to Diabetic control also but statistically higher effects compared to the DVE treated groups (Table 5). 


\begin{tabular}{|c|c|c|c|c|c|c|}
\hline \multirow[b]{2}{*}{ Treatment } & \multicolumn{6}{|c|}{ Serum Biochemical Parameters } \\
\hline & AST $(\mu \mathrm{mol} / \mathrm{L})$ & ALT $(\mu \mathrm{mol} / \mathrm{L})$ & $\operatorname{ALP}(\mu \mathrm{mol} / \mathrm{L})$ & $\begin{array}{c}\text { TBIL } \\
(\mathrm{mmol} / \mathrm{L})\end{array}$ & TP (g/dl) & $\operatorname{ALB}(g / d l)$ \\
\hline NDC & $31.0 \pm 1.83^{\mathrm{a}}$ & $34.8 \pm 2.22^{\mathrm{a}}$ & $109.3 \pm 3.59^{b}$ & $2.7 \pm 0.32^{\text {cd }}$ & $74.4 \pm 3.76^{\mathrm{e}}$ & $42.6 \pm 0.81^{\mathrm{a}}$ \\
\hline DC & $351.0 \pm 8.83^{g}$ & $227.3 \pm 1.70^{\mathrm{d}}$ & $234.0 \pm 4.83^{\mathrm{f}}$ & $2.9 \pm 0.29^{d}$ & $31.1 \pm 3.03^{\mathrm{a}}$ & $143.1 \pm 3.51^{\mathrm{g}}$ \\
\hline DVE $(400 \mathrm{mg} / \mathrm{kg})$ & $329.3 \pm 5.48^{\mathrm{f}}$ & $224.5 \pm 4.20^{\mathrm{d}}$ & $229.3 \pm 6.95^{\mathrm{f}}$ & $2.7 \pm 0.42^{\text {cd }}$ & $34.0 \pm 3.68^{\mathrm{ab}}$ & $138.0 \pm 1.74^{\mathrm{f}}$ \\
\hline DVE $(800 \mathrm{mg} / \mathrm{kg})$ & $267.5 \pm 6.68^{\mathrm{d}}$ & $177.5 \pm 2.65^{\mathrm{c}}$ & $218.0 \pm 3.74^{\mathrm{e}}$ & $2.5 \pm 0.31^{\mathrm{bc}}$ & $37.0 \pm 2.91^{\mathrm{bc}}$ & $119.6 \pm 2.27^{\mathrm{e}}$ \\
\hline DVE $(400 \mathrm{mg} / \mathrm{kg})+\mathrm{ACA}(150 \mathrm{mg} / \mathrm{kg})$ & $87.8 \pm 2.22^{\mathrm{c}}$ & $74.3 \pm 3.95^{\mathrm{b}}$ & $118.8 \pm 3.86^{c}$ & $1.5 \pm 0.26^{\mathrm{a}}$ & $46.2 \pm 0.78^{d}$ & $96.5 \pm 3.07^{\mathrm{c}}$ \\
\hline DVE $(800 \mathrm{mg} / \mathrm{kg})+$ ACA $(150 \mathrm{mg} / \mathrm{kg})$ & $72.3 \pm 3.74^{\mathrm{b}}$ & $71.5 \pm 2.08^{b}$ & $89.3 \pm 2.75^{\mathrm{a}}$ & $1.1 \pm 0.13^{\mathrm{a}}$ & $49.2 \pm 1.09^{d}$ & $86.3 \pm 1.54^{b}$ \\
\hline ACA $(150 \mathrm{mg} / \mathrm{kg})$ & $302.5 \pm 5.51^{\mathrm{e}}$ & $182.8 \pm 8.46^{c}$ & $169.0 \pm 4.76^{\mathrm{d}}$ & $2.1 \pm 0.21^{b}$ & $38.6 \pm 1.86^{c}$ & $103.1 \pm 1.32$ \\
\hline
\end{tabular}

Data is represented as mean \pm S.D $(n=4)$. Mean values having different lowercase letters down the columns and uppercase letters across the row as superscripts are considered significant $(p<0.05)$.

\section{Discussion}

Diabetes mellitus is a multifactorial disease characterized by persistent elevation of blood glucose, resulting from a defect in cessation of insulin secretion or synthesis, or peripheral resistance to insulin action or both 1 . It affects the metabolism of carbohydrates, fats and proteins in the body, leading to several complications such as neuropathy, nephropathy and retinopathy [12]. The management of hyperglycemia is the hallmark of treatment in diabetes. The primary aim of diabetes management is to reduce blood glucose levels to within the normal range. Various hypoglycemic medications are available for this purpose but most of them are not without severe adverse effects. Consequently, some diabetics often resort to medicinal plants and foods with anti: diabetic activity but with fewer or no adverse effects while some co: use anti: aiabetic herbs with conventional anti: diabetic agents for better glycemic control. Many herbal extracts have been reported for their anti: diabetic activities as their principal bioactive components showed good anti: diabetic and anti: oxidant properties [13] and are being used for the treatment of diabetes. This study investigated the pharmacological effects of methanol extract of Desmodium velutinum leaves and its co: administration with acarbose in diabetic Wistar rats.

The phytochemical analysis of the extract revealed the presence of tannins, alkaloids, saponins, terpenoids, steroids, and flavonoids in varying proportions. This is in agreement with the study of [14] who reported the presence of these phytochemicals in the leaf extract of Desmodium velutinum.

The acute toxicity study of the extract $(10: 2900 \mathrm{mg} / \mathrm{kg})$ produced no significant physical signs of toxicity such as writhing, weakness, anorexia, gasping, and palpitation, reduction in body weight, decreased respiratory rate or death within 24 hours of post: Administration. The extract of $5000 \mathrm{mg} / \mathrm{kg}$ produced some significant physical signs of toxicity such as weakness, palpitation and gasping among the animals eventually resulting into the death before 24 hours of post: administration. Hence the oral median lethal dose (LD50) of the extract was therefore estimated to be 3807.8 $\mathrm{mg} / \mathrm{kg}$. The result of this study is in agreement with the report 15 where the result of LD50 was greater than $3000 \mathrm{mg} / \mathrm{kg}$ showing that $D$. velutinum extract is relatively safe for human consumption. This is however contrary to the reports of $[15,16]$ where the oral administration of methanol extract of Desmodium velutinum leaves produced no physical signs of toxicity such as weakness, writhing, gasping, palpitation, anorexia, reduction in body weight, decreased respiratory rate or death up to the highest administered oral dose ( $5000 \mathrm{mg} / \mathrm{kg}$ body weight) within $24 \mathrm{~h}$ of post: administration. The oral $\mathrm{L} D_{50}$ of DVE in mice was thus established to be greater than $5000 \mathrm{mg} / \mathrm{kg}$.

Experimental diabetes was induced in rats with the use of alloxan. Alloxan induces diabetes by damaging the insulin producing pancreatic beta: cells of the islets of Langerhans resulting in reduced synthesis and release of endogenous insulin [17]. The cytotoxic action of alloxan induced diabetes is mediated by reactive oxygen species with a simultaneous massive increase in cytosolic calcium concentration leading to a drastic total destruction of beta: cells producing type 1: like diabetes mellitus [18]. In this study, result obtained showed that the methanol extract of Desmodium velutinum leaves produced significant reduction in blood glucose level in alloxan induced hyperglycemic rats in a dose and time dependent manner. This is totally in agreement with those of other researchers, who systematically demonstrated that extracts of various parts of the plant (leaves, roots, stems, flowers and seeds) possess antidiabetic properties [19, 20]. Its anti: diabetic activity might be as a result of the depression of gluconeogenic enzymes 
or inhibition of glucose:6:phosphatase in the liver by the extract, and subsequent reduction in glucose release to the blood [21]. Its anti: diabetic role could also be attributed to the synergistic role of the extract constituents (flavonoids saponins, steroids, alkaloids and terpenoids) present in Desmodium velutinum. Flavonoids and tannins have been reported to cause regeneration of damaged pancreatic islets, stimulate calcium and glucose uptake [22, 23]. These compounds are known to be responsible for the hypoglycemic activity of the plant as compared with other hypoglycemic plants which contains similar phytoconstituent found in Luffa acutangula fruit extract [24] and methanol root bark extract of Acacia albia [25]. Most of the anti: diabetic plants show various mechanisms of antidiabetic activity like alteration of glucose metabolism, insulin: like effect, improve glucose tolerance, reduction of absorption of glucose from intestine, enhancing insulin signal pathway, hypoglycemia through increase glucose uptake and glycogen synthesis, generation of beta cell in pancreas [26]. Varied phytochemical constituents in the methanolic extract of Desmodium velutinum as found in this study and concluded it may account for the varied ethnobotanical uses of the plant in folk medicine in Nigeria and hence tipped it to be a very rich source of drug formulation and their use in various therapeutic trials.

The anti: hyperglycemic activity of the extract alongside acarbose compared to the hyperglycemic control was greater than the anti: hyperglycemic activity of the extract alone. Also, the anti: hyperglycemic activity of the extract alongside acarbose was greater when compared to that of acarbose alone. This connotes that the extract and acarbose showed additive anti: diabetic activities. Therefore, in the management of diabetes, Desmodium velutinum can play a significant role.

The body weights of the rats in all the hyperglycemic groups showed a decrease in the first week. This observation could be attributed to the increased conversion of storage fat and proteins to glucose (gluconeogenesis) [27]. However, after the first week, the body weights of both the treated hyperglycemic groups showed a steady increase, probably with improvement in glucose uptake by cells, though with no significant difference throughout the course of the experiment. The result of this study is in agreement with that of Kim, et al. [28] which determined the effect of leptin sensitivity in adult and aged rats and found a slight increase in weight after an initial fall (in the first week) in adult rats given metformin. This study reveals lightly significant difference in the weights of the rats in the treated groups compare with diabetic control and normal control suggesting that the use of Desmodium velutinum extract and acarbose by diabetics will not bring about an increase in weight.

In an inflammatory situation, there is a leakage of cytoplasmic enzymes into circulation in this study, increase in serum levels of
AST and ALT was observed in alloxan: induced diabetic animals. The increased level of AST may be due to necrosis, Myocardial infarction and hepatocellular damage, while the increased serum level of ALT may be due to inflamed liver cells. In medicine, the presence of elevated values of ALT and AST is indicative of liver damage [29]. This is in agreement with the study by Derosa, et al. [30] where there was an increased in serum AST and ALT levels after the administration of alloxan to Wistar rats. It was also discovered by Recknagel [31] that there was an increased level of AST in gross cellular necrosis, as in Streptozotocin: induced diabetes: damaged to the pancreatic cells of diabetic rats. It has also been observed by Jensen, et al. [32] that liver which has been inflamed or undergoes cell death caused serum increased in ALT and liver with myocardial infarction and hepatocellular damaged induced increased level of AST. The observation that the activity of serum AST appeared to be more elevated than ALT, is also in agreement with the findings of Recknagel, Tanaka, et al. [31, 33] and Nanbara, et al. [34] that AST rise high and had more activity than did ALT in the serum of diabetic mice. This study revealed that treatment of alloxan: induced diabetic rats with $D$. velutinum extract, acarbose and various doses of extract alongside acarbose administrations brought about decrease of the transaminases activity. The rate of decrease occurred in a dose: dependent fashion with the $800 \mathrm{mg} /$ kg extract: treated group showing the most reduction among the extract: alone treated groups. An additive effect was seen when the extract was co: administered with acarbose, as they produced the highest reduction compared to the extract and acarbose alone treated groups. Reduced levels of ALT and AST in rats treated with the extract could also be attributed to the hepatoprotective ability of some bioactive compounds of the extract to prevent the metabolism of alloxan into more toxic metabolite and minimized the production of free radicals. Some herbal plants possess hepatoprotective effects. This is in agreement with Lipkin [35] where humans were administered with variety of herbal plants that contains saponin and they proved to be potent against cancer and hepatic cell proliferation.

There was an observed increase in ALP activity in the diabetic control group suggesting hepatocellular damage after induction of diabetes in rats with alloxan. Several studies have reported similar elevation in the activities of serum AST, ALT and ALP during alloxan administration [36, 37]. The study revealed that serum ALP activities were return back to near normal after 28days of treatment with the extract, acarbose as well as the administration of the extract alongside acarbose in alloxan diabetic rats which indicated the defensive and specifically the non: toxic nature of the bioactive polyphenolic compounds in the plant extract, because ALP level acts as indicator of liver function. ALP activity is considered as good 
indication on the hepatotoxic nature of alloxan induced diabetic rats.

There was an observed increase in plasma bilirubin produced in the diabetic control when compared to treated groups. Treatment of alloxan: induced diabetic rats with graded doses of $D$. velutinum extract and acarbose alone treated group showed a significant reduction in serum total bilirubin produced compared to the untreated diabetic rats. The various doses of the administration of the extract alongside acarbose, through synergistic interaction brought about a greater significant decrease in serum bilirubin concentration. According to Rana et al. [38] increase in plasma bilirubin (hyper: bilirubinemia) in alloxan: treated rats may be as a result of a decrease in liver uptake, conjugation or increased bilirubin production from hemolysis. Also, the plasma bilirubin elevation in diabetic rats indicates alteration in liver function as confirmed by the changes in the plasma enzymes activities. The hepatoprotective potentials of the extract and extract alongside acarbose administration were observed in the reversal of increase in serum bilirubin levels.

Serum total protein concentration in diabetic control group was significantly decreased when compared with the diabetic treated groups and normal control. A number of factors that might be responsible for this reduction include decrease due to proteinuria and albuminuria, which are important clinical markers of diabetic nephropathy [39] and due to increased protein catabolism [40] as a result of insulin deficiency from free radical generation due to alloxan induction, since it has been established that insulin stimulates the incorporation of amino acids into protein [40]. Also, increased rate of amino acids conversion to glucose 41, decreased amino acid uptake [41], and increased conversion rate of glucogenic amino acids to $\mathrm{CO}_{2}$ and $\mathrm{H}_{2} \mathrm{O}$ [42]. The results of this study showed that, the treatment of diabetic rats with the plant extract, acarbose and the administration of the plant extract alongside acarbose groups brought about marked increase in serum total protein contents. The extract alongside acarbose combinations showed strong effect as total elevations of protein and decrease albumin level were observed in these groups. The elevation level could be as a result of high hepatic uptake of amino acids, stimulation of amino acid incorporation into protein and decreased proteolysis by activating the enzyme that catalyzes amino acids transamination.

\section{Conclusion}

This study revealed that Desmodium velutinum extract possesses antidiabetic activity and exhibits additive pharmacological effects with acarbose. This pharmacological interaction with acarbose could play a significant role in the management of diabetes and its associated complications.

\section{Conflict of Interest}

The authors declare that there is no conflict of interest.

\section{References}

1. Alam Khan, Goher Zaman, Richard A Anderson (2009) Bay leaves improve glucose and lipid profile of people with Type 2 diabetes. J Clin Biochem Nutr 44(1): 52-56.

2. Robert WC (2001) Ultrasound imaging: Principles and applications in rodent research. ILAR J 42(3): 233-247.

3. J P Yadav, Sushila Saini, A N Kalia, A S Dangi (2008) Hypoglycemic activity extract of Salvadora oleoides in normal and alloxan induced diabetes rats. Indian J Pharmacol 40(3): 23-27.

4. M D Ivorra, M Payá, A Villar (1989) A review of natural products and plants as potential antioxidant drugs. J Ethnopharmacol 27: 243-275.

5. Asare EO, Shehu T, Agishi EA (1984) Preliminary studies on indigenous species for dry season grazing in the northern guinea savanna zone of Nigeria. Tropical Grassland 18: 148-152.

6. Akinola JO, Afolayan RA, Alorunju SAS (1991) Effect of storage, testa colour and scarification method on seed germination of Desmodium velutinum (wild) DC. Seed science and technology 19: 159-166.

7. Anowi CF, Onyegbule AF, Onyekaba T, Azode C (2012) Antipyretic and phytochemical evaluation of the ethanol extract of the leaves of Desmodium velutinum. Asian Journal of Pharmacy Life Sciences 2: 135143.

8. Sofowara A (2006) Medical plants and traditional medicine in Africa. Reprint edition, Spectrum Books Ltd., Ibadan.

9. Lorke D (1983) A new Approach to Practical Acute Toxicity Testing. Archives of Toxicology 54(4): 275-287.

10. Dunn J S, McLetchie N G B (1943) Experimental alloxan diabetes in the rat.Lancet.11 (245) 384-387.

11. Reitman S, Frankel S (1957) Methods for the determination of serum biochemical parameters. America Journal of Clinical Pathology: 28: 56

12. Anthony J Afolayan, Taofik O Sunmonu (2010) In vivo studies on antidiabetic plants used in South African Herbal Medicine. J Clin Biochem Nutr 47(2): 98-106

13. Kunyanga CN, Imungi JK, Okoth MW, Biesalski HK, Vadivel V (2012) Total phenolic content, antioxidant and antidiabetic properties of methanolic extract of raw and traditionally processed Kenyan indigenous food ingredients. LWT-Food Science and Technology 45(2): 269-276.

14. Maria Ida Maiorino, Giuseppe Bellastella, Katherine Esposito (2014) Diabetes sexual dysfunction: current perspectives. Diabetes, Metab Syndrome and Obes 7: 95-105.

15. C Mallidis, I Agbaje, N McClure, S Kliesch (2011) The influence of diabetes mellitus on male reproductive function: a poorly investigated aspect of male infertility. Urologe A 50(1): 33-37.

16. Ezike AC, Akah PA, Okoli C O, Ufere IK, Ezeudu E, et al. (2014) Studies on gastrointestinal effects of desmodium velutinum: a traditional remedy for diarrhea. American Journal of Pharmacology and Toxicology 9(2): 114-124.

17. Ghosh MN (2005) Fundamentals of Experimental Pharmacology. 3rd Edition. Calcutta: Hilton and Company: Pp. 184.

18. Szkudelski T (2001) The mechanism of alloxan and streptozotocin action in beta cells of rat pancreas. Physiol Resource 50(2): 537-546. 
19. Dolly Jaiswal, Prashant Kumar Rai, Amit Kumar, Shikha Mehta, Geeta Watal (2009) Effect of Moringa oleifera Lam. leaves aqueous extract therapy on hyperglycemic rats. J Ethnopharmacol 123(3): 392-396.

20. Neil D, Vogel G, Hagler M, Kors D, Hennessey A (1990) Diminished sexual activity in a new animal model of depression. Neurosci Biobehav 14: 7376.

21. L Rato , M G Alves, T R Dias, G Lopes, J E Cavaco, et al. (2013) Highenergy diets may induced a pre-diabetic state altering testicular glycolytic metabolic profile and male reproductive parameters. Andrology 1(3): 495-504.

22. A Scoppola, F R Montecchi, G Menzinger, A Lala (2001) Urinary mevalonate excreation rate in type 2 diabetes: Role of metabolic control. Antherosclerosis 156 (2): 357-361.

23. Sonmez M, A Yuce, Turk G (2007) The protecttice effect of melatonin and Vitamin E on anti-oxidant enzyme system activities and epididymal sperm characteristics of homocycysteine treated male rats. Reprod Toxicol 23(2): 226-231.

24. Sandro La Vignera, Rosita Condorelli, Enzo Vicari, Rosario D Agata, Aldo E Calogero (2012) Diabetes mellitus and sperm parameters. J Androl 33(2): 145-153. [Jangir RN, Jain GC (2014) Diabetes mellitus induced impairment of male reproductive functions: A review. Curr Diabetes Rev 10(3): 147-157.

25. Tamas V, Kempler P 2014 Sexual dysfunction in diabetes. Handb Clin Neurol 126: 223-232.

26. N H Ugochukwu, N E Babady, M Cobourne, S R Gasset (2003) The Effect of Gangronema latifoliu extracts on serum lipid profile and oxidative stress in hepatocytes of diabetic rats. J Biosci 28(1): 1-5.

27. Champe P, Harvey, R and Ferrier D (2005) Lipid metabolism. Lippincott's Illustrated Review: Biochemistry. Indian edition, Jaypee Brothers: Medical Publisher (P) Ltd: 171-217.

28. Kim S R, Park S, Kim J Y, Kim Y W (1996) Metformin enhances leptin sensitivity in aged rats. Korean Journal of Physiology and Pharmacology 10(12): 1-6.

29. Giboney PT 2005 Mildly elevated liver transaminase levels in the asymptomatic patient. America Family Physician:71(6): 1105-1110.

30. Giuseppe Derosa, Antonio V Gaddi, Mario N Piccinni, Leonardina Ciccarelli, Sibilla Salvadeo (2005) Antithrombotic effects of rosiglitazone metformin versus glimepiride metformin combination therapy in patients with type II diabetes mellitus and metabolic syndrome. Pharmacotherapy 25(1): 637-645.

31. Recknagel R O (1987) Carbon tetrachloride hepatotoxicity. Pharmacol Rev 19(2): 145-195.

32. Jensen JE, Stainberg SE, Freese P, Marino E (2004) Liver function tests. Journal of Digestive Disorder 6: 1-3.

33. K Tanaka, S Nanbara, $\mathrm{T}$ Tanaka, $\mathrm{H}$ Koide, $\mathrm{T}$ Hayashi (1988). Aminotransferase activity in the liver of diabetic mice. Diabetes Res Clin Pract: 5(5): 71-75.

34. S Nanbara , K Tanaka, H Koide, T Tanaka, T Hayashi (1990) Changes on levels of B6 vitamin and aminotransferase on the liver of diabetic animals diabetes. Diabetes Res Clin Pract 9(2): 109-114.

35. Lipkin R (1995) Secondary plant metabolites. Science News 14: 8-9.

36. Etuk EU, Muhammed BJ (2010) Evidence based of chemical method of induction of diabetes mellitus in experimental animals. Asian Journal Experimental Biological Science1(2): 331-336.

37. Owolabi OJ, Amaechina FC, Okoro M (2011) Effect of ethanol leaf extract of New bouldia laevis on blood glucose levels of diabetic rats. Tropical Journal of Pharmaceuticals Research:10(3): 249-254.

38. S V Rana, R Singh, S Verma (1996) Protective effects of few antioxidants on liver function in rats treated with Cadmium and Mercury. Indian J Exp Biol 34 (2): 177- 179

39. Mauer SM, Steffes MW, Brown DM (1981) The kidney in diabetes. America Journal of Medicine. 70603.

40. T P Almdal, H Vilstrup (1988) Strict insulin treatment normalizes the organic nitrogen contents and the capacity of urea-N synthesis in experimental diabetes in rats. Diabetologi 31(2): 114-118.

41. Chang An Chu, Stephanie M Sherck, Kayano Igawa, Dana K Sindelar, Doss W Neal, et al. (2007) Effects of free fatty acids in hepatic glycogenolysis and gluconeogenesis in conscious dogs. Am J Physiol: Endocrinol Metab 282 (3): 402-411.

42. Garber AJ (1980) The impact of STZ-induced diabetes mellitus on cyclic nucleotide regulation of skeletal muscle amino acid metabolism in the rat. J Clin Invest 65 (2): 478- 487. 